\title{
Importance of light and oxygen for photochemical reactivation in photosynthetic stromatolite communities after natural sand burial
}

\author{
Rupert G. Perkins ${ }^{1, *}$, Jacco C. Kromkamp ${ }^{2}$, R. Pamela Reid ${ }^{3}$ \\ ${ }^{1}$ School of Earth, Ocean and Planetary Sciences, Cardiff University, Cardiff CF10 3YE, UK \\ ${ }^{2}$ Netherlands Institute of Ecology, Centre for Estuarine and Marine Ecology (NIOO-CEME), PO Box 140, 4400 AC Yerseke, \\ The Netherlands \\ ${ }^{3}$ University of Miami/RSMAS-MGG, 4600 Rickenbacker Causeway, Miami, Florida 33149, USA
}

\begin{abstract}
Modern stromatolites at Highborne Cay, Exuma, Bahamas are formed in a high energy environment, where turbulent mixing of the water column supplies the sand particles that are trapped and bound by microbial phototrophs. The photosynthetic communities consist of cyanobacteria within the surface fabric of the stromatolite, and surface eukaryotic microalgae (e.g. diatoms and chlorophytes). Due to the turbulent environment, stromatolites are often buried for periods of weeks or months as a result of sand wave movements. We investigated the tolerance of subsets of the photosynthetic communities in stromatolites to natural burial processes. Variable chlorophyll fluorescence was used to monitor PSII quantum efficiency and fluorescence kinetics during and after artificial and natural in situ burial. Excavated samples with an intact cyanobacterial community, but lacking surface microalgae, reactivated their quantum efficiency when exposed to both low light and oxygen. Reactivation, indicated by an increase in photochemical efficiency $\left(\Delta F / F_{\mathrm{m}}\right)$, occurred after 7 to $9 \mathrm{~d}$ and 14 to $16 \mathrm{~d}$ of natural burial, although reactivation was slower with longer burial. Changes in fluorescence yields indicated that probable state transitions occurred, and we suggest that some form of oxygen dependent process(es) and light were in part responsible for the re-establishment of photochemistry. These processes effectively 'kick start' electron transport, and hence protect against photodamage induced by exposure to light after burial. In contrast to the prokaryotic cyanobacterial mats, mats with surface communities dominated by diatoms did not have high tolerance to burial. Two out of 3 samples of diatom mats failed to reactivate after $7 \mathrm{~d}$ of burial. The greater ability of cyanobacteria to survive week to month long periods of burial may be an important factor in accounting for the importance of these prokaryotes in stromatolite construction.
\end{abstract}

KEY WORDS: Cyanobacteria · Electron Transport - Fluorescence · PSII · Quantum efficiency • Stromatolites Resale or republication not permitted without written consent of the publisher

\section{INTRODUCTION}

Bahamian stromatolites are the only large modern examples of columnar stromatolites forming in open marine conditions. Bahamian columns can be up to $2 \mathrm{~m}$ in height, rivalling many ancient examples (Dill et al. 1986). While it is likely that stromatolite formation has altered during a 3 billion (or more) year history, modern examples are key to understanding the processes that form these remarkably persistent organosedimentary structures (Riding 2000).

Bahamian stromatolite growth is concentrated in the millimetric surficial mat of photosynthetic and heterotrophic microbes. Cyanobacteria and algae trap and bind sedimentary grains, driving overall column accretion (Riding et al. 1991, Reid et al. 2000). As they die, the remains of these primary producers are decomposed by heterotrophic bacteria, and some of these 
decay processes stimulate $\mathrm{CaCO}_{3}$ precipitation that cements the trapped grains (Reid et al. 2000, Visscher et al. 2000, Andres et al. 2006). This initiates lithification that ultimately can preserve stromatolites for billions of years. Processes of accretion and lithification are therefore fundamental to stromatolite formation (Riding 2000).

Cyanobacteria are ubiquitous in Bahamian stromatolite mats, but microalgae are also locally abundant (Riding et al. 1991). The relative roles of these photosynthetic communities have been long debated (e.g. Riding et al. 1991, Browne et al. 2000). Bahamian stromatolitic mats form in high energy habitats, such as shorelines and tidal channels, in which they are frequently buried by mobile sandy sediments, on daily, weekly, monthly and annual timescales (Dill et al. 1986, Riding et al. 1991). At first sight, burial would appear deleterious, since it may kill the photosynthetic communities, and hinder further growth until unburial occurs. However, since growth of these stromatolites requires grains to be delivered to the accreting upper surface, the columns form in habitats where burial occurs frequently. Furthermore, the height from the seafloor to which currents can transport grains may determine column height (Riding et al. 1991). In this view, temporary burial by sediment may well be necessary for stromatolite growth. Nonetheless, burial could significantly impact growth of the phototrophic algal and cyanobacterial stromatolitic mat communities that dominate the surface matrix.

In the present study, the photophysiology of 2 stromatolite mat types were compared: (1) mat communities dominated by filamentous cyanobacteria within the surface matrix of the stromatolite, and (2) mats with surface communities dominated by stalked diatoms, principally Licmophora spp. (G. Underwood pers. comm.). Previous work on Bahamian stromatolites demonstrated the role of reductions in oxygen and light in inactivation of photochemistry in mats dominated by cyanobacteria (Kromkamp et al. 2007). Specifically, photosystem II (PSII) quantum efficiency decreased when stromatolite samples were artificially buried in closed containers under sand collected from the same sampling site, and efficiency was restored after exhumation of the samples and application of fresh seawater. The present study extends this work to the natural system, by analyzing samples collected from stromatolites buried in situ for periods of known duration. Variable chlorophyll fluorescence measurements were used to monitor the quantum efficiency and fluorescence yields during exposure to low light and oxygen. The goal was to test the hypothesis that a combination of oxygen and light is required as the stimulus for reactivation of photochemistry after exposure following natural burial under sand.

\section{MATERIALS AND METHODS}

Samples were excised from stromatolites formed in shallow water on the eastern beach (Stromatolite Beach) of Highborne Cay, Exuma Sound, Bahamas $\left(76^{\circ} 49^{\prime} \mathrm{W}, 24^{\circ} 43^{\prime} \mathrm{N}\right)$. All samples were quickly returned to the laboratory onboard the RV 'F.G. Walton Smith' for fluorescence measurements. All fluorescence measurements were made using a Walz WaterPAM fluorimeter equipped with either the EDF (red light measuring beam and actinic light for cyanobacteria) or EDF/B (blue light measuring beam and actinic light for diatoms and chlorophyta) detectors. Fluorimeter settings produced a low frequency, non-actinic measuring beam and a $0.6 \mathrm{~s}$ saturating pulse of over $8000 \mu \mathrm{mol} \mathrm{m}{ }^{-2} \mathrm{~s}^{-1}$ photosynthetically active radiation (PAR). The signal gain was set as low as possible (typically setting 2 ) with the photomultiplier gain set to 4 or 5 , resulting in fluorescence yields in excess of 300 units for all measurements. Measurements of minimum or operational yield $\left(F_{\mathrm{o}}\right.$ in the dark and $F$ in the light, respectively) and maximum fluorescence yield ( $F_{\mathrm{m}}$ in the dark and $F_{\mathrm{m}}{ }^{\prime}$ in the light) were made, with calculations of PSII quantum efficiency following Genty et al. (1989):

or,

$$
\begin{aligned}
\Delta F / F_{\mathrm{m}} & =\left(F_{\mathrm{m}}-F_{\mathrm{o}}\right) / F_{\mathrm{m}} \\
\Delta F / F_{\mathrm{m}}{ }^{\prime} & =\left(F_{\mathrm{m}}{ }^{\prime}-F\right) / F_{\mathrm{m}}{ }^{\prime}
\end{aligned}
$$

for measurements in the dark and light, respectively.

For samples collected in 2006, rapid light curves (RLC) of relative electron transport rate (rETR) versus light level (PAR) were obtained at the end of the measurement period. rETR was calculated as the product of $\Delta F / F_{\mathrm{m}}{ }^{\prime}$ and PAR/2 (Sakshaug et al. 1997, Perkins et al. 2006). RLCs used a light range of 0 to $880 \mu \mathrm{mol}$ $\mathrm{m}^{-2} \mathrm{~s}^{-1} \mathrm{PAR}$, with increasing incremental light steps of $30 \mathrm{~s}$ using the pre-programmed software accompanying the Water-PAM fluorimeter. Light levels were calibrated in advance using a Licor cosine-corrected quantum sensor. Light curve parameters of maximum electron transport rate $\left(\mathrm{rETR}_{\max }\right)$ and the initial slope of the light curve $(\alpha)$ were solved using the model of Eilers \& Peeters (1988). The light saturation coefficient $\left(E_{K}\right)$ was calculated as $\mathrm{rETR}_{\max } / \alpha$.

Initial study of artificial burial compared to dark treatment. The methodologies of all burial experiments are summarised in Table 1 . The first 2 samples were collected in January 2005, and consisted of stromatolites mats with no visible (low power light microscopy) eukaryotic microalgal surface growth. These samples were known to have been buried under sand in situ within 4 wk prior to measurements, but were not buried when collected (R. Reid pers. comm., authors' pers. obs.). Samples were cut from the stromatolite using a knife to form a sample at least 
Table 1. Summary of methods used for the initial ex situ burial experiment, 2 natural burial experiments carried out on cyanobacteria, and the ex situ burial experiment on the surface microalgae. For all burial experiments $\mathrm{n}=3$, except the initial ex situ burial experiment $(n=1)$. RLC: rapid light curve

\begin{tabular}{|c|c|c|}
\hline Sample collected & Photosynthetic community & Methodology \\
\hline $\begin{array}{l}\text { Initial experiment with } \\
\text { buried sample ex situ }\end{array}$ & $\begin{array}{l}\text { Cyanobacteria with no visible } \\
\text { surface eukaryotes }\end{array}$ & 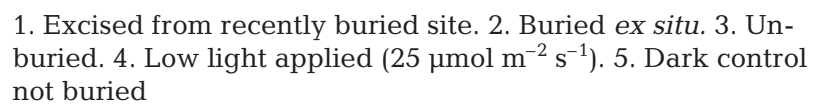 \\
\hline $\begin{array}{l}\text { Naturally buried sample } \\
\text { buried for } 7-9 \mathrm{~d}\end{array}$ & Cyanobacteria & 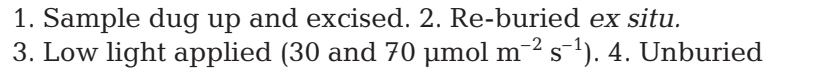 \\
\hline $\begin{array}{l}\text { Naturally buried sample } \\
\text { buried for } 14-16 \mathrm{~d}\end{array}$ & Cyanobacteria & $\begin{array}{l}\text { 1. Sample dug up and excised. 2. Re-buried ex situ. } 3 \text {. Oxygen } \\
\text { applied whilst buried ( } 60 \mathrm{~min}) .4 \text {. Low light applied ( } 30 \text { and } \\
\left.70 \mu \mathrm{mol} \mathrm{m} \mathrm{m}^{-2} \mathrm{~s}^{-1}\right) .5 \text {. Unburied }\end{array}$ \\
\hline $\begin{array}{l}\text { Unburied sample buried } \\
\text { ex situ for } 7 \mathrm{~d}\end{array}$ & Surface microalgae & $\begin{array}{l}\text { 1. Sample excised. 2. Buried for } 7 \mathrm{~d} \text {. } 3 \text {. Unburied in darkness. } \\
\text { 4. Low light applied }\left(30 \text { and } 70 \mu \mathrm{mol} \mathrm{m}^{-2} \mathrm{~s}^{-1}\right) \text {. 5. RLC constructed }\end{array}$ \\
\hline
\end{tabular}

$1 \mathrm{~cm}$ thick and with a surface area of approximately $4 \mathrm{~cm}^{2}$. The samples were placed in pots containing seawater collected from the sample site (all seawater and sand used for burial experiments were collected from the sample site) and returned to the laboratory, where measurements were commenced within $20 \mathrm{~min}$ of sampling. The first sample was maintained in seawater in darkness as a control. The second sample was buried under a mixture of seawater and sand to an overlying depth of $3 \mathrm{~cm}$. The sample was buried with the fluorimeter fibre-optic probe just touching the surface. PSII quantum efficiency was monitored for both samples. The second sample was unburied when the quantum efficiency reached a minimum value (zero), kept in darkness and then exposed to low light ( $\left.25 \mu \mathrm{mol} \mathrm{m} \mathrm{m}^{-2} \mathrm{~s}^{-1} \mathrm{PAR}\right)$.

Naturally buried stromatolite samples. Samples of stromatolite mats dominated by cyanobacteria within the surface stromatolite fabric (Fig. 1) were collected in July 2006 from areas monitored by the Research Initiative on Bahamian Stromatolites (RIBS) project, such that the duration of natural in situ burial under sand was known (R. Reid, pers. comm.). Samples were carefully dug up and excised, followed by rapid re-burial under sand and sea water in plastic containers for transport back to the laboratory. Once in the laboratory, samples were quickly unburied and then reburied in a $200 \mathrm{ml}$ sample pot, using sand and sea water to an overlying depth of $3 \mathrm{~cm}$, with the fluorimeter probe in position just touching the stromatolite surface. The sample pot was maintained in a water bath in the laboratory for the duration of the experiment, holding the temperature at approximately $25^{\circ} \mathrm{C}$. Measurements of fluorescence yields, PSII quantum efficiency and RLCs were obtained for 2 treatments carried out on separate samples. The first treatment exposed the samples to 60 min of low light at 2 photon flux levels (30 and $70 \mu \mathrm{mol} \mathrm{m}{ }^{-2} \mathrm{~s}^{-1} \mathrm{PAR}$ ) while the sample was still buried by using the actinic light from the fluorimeter probe. The sample was then unburied to allow exposure to fresh oxygenated seawater. The second treatment (to a separate sample) applied oxygen bubbled into the sample using a fine tube ( $3 \mathrm{~mm}$ diameter) positioned next to the fibre optic probe of the fluorimeter. Oxygen was applied for $60 \mathrm{~min}$ prior to exposure to low light, again while the sample was still buried. After a further $60 \mathrm{~min}$, the sample was unburied and fresh seawater was applied. All measurements were carried out 3 times for each treatment, with each set of measurements run on successive days (one sample per replicate and one replicate per day, due to the time required for one set of measurements). As a result, samples differed by $1 \mathrm{~d}$ in the duration of natural burial (one sample was tested per day), such that samples for the low light treatment were buried for 7, 8 and $9 \mathrm{~d}$ and samples for the oxygen and low light experiment were buried for 14, 15 and $16 \mathrm{~d}$ (for simplicity, these are referred to as replicates hereafter).

Reactivation of surface microalgae in artificially buried stromatolite samples. Samples were collected in July 2006 from a site where the surface of the stromatolite was colonised by a thick growth of microalgae, principally the diatom Licmophora spp. (Fig. 2; G. Underwood pers. comm.). The samples were transported back to the laboratory, where they were buried under sand and seawater in $200 \mathrm{ml}$ plastic pots for $7 \mathrm{~d}$. After this period, the samples were unburied and PSII quantum efficiency, fluorescence yields and RLCs were measured as described above. To ensure that the fluorimeter detected only the signal from the surface microalgae, and not the underlying cyanobacteria, the immersed samples were positioned on their sides, held in place by sand. The fluorimeter probe was then placed parallel to the stromatolite surface and aimed at the surface microalgal growth extending several $\mathrm{mm}$ from the stromatolite sample surface. Measurements 


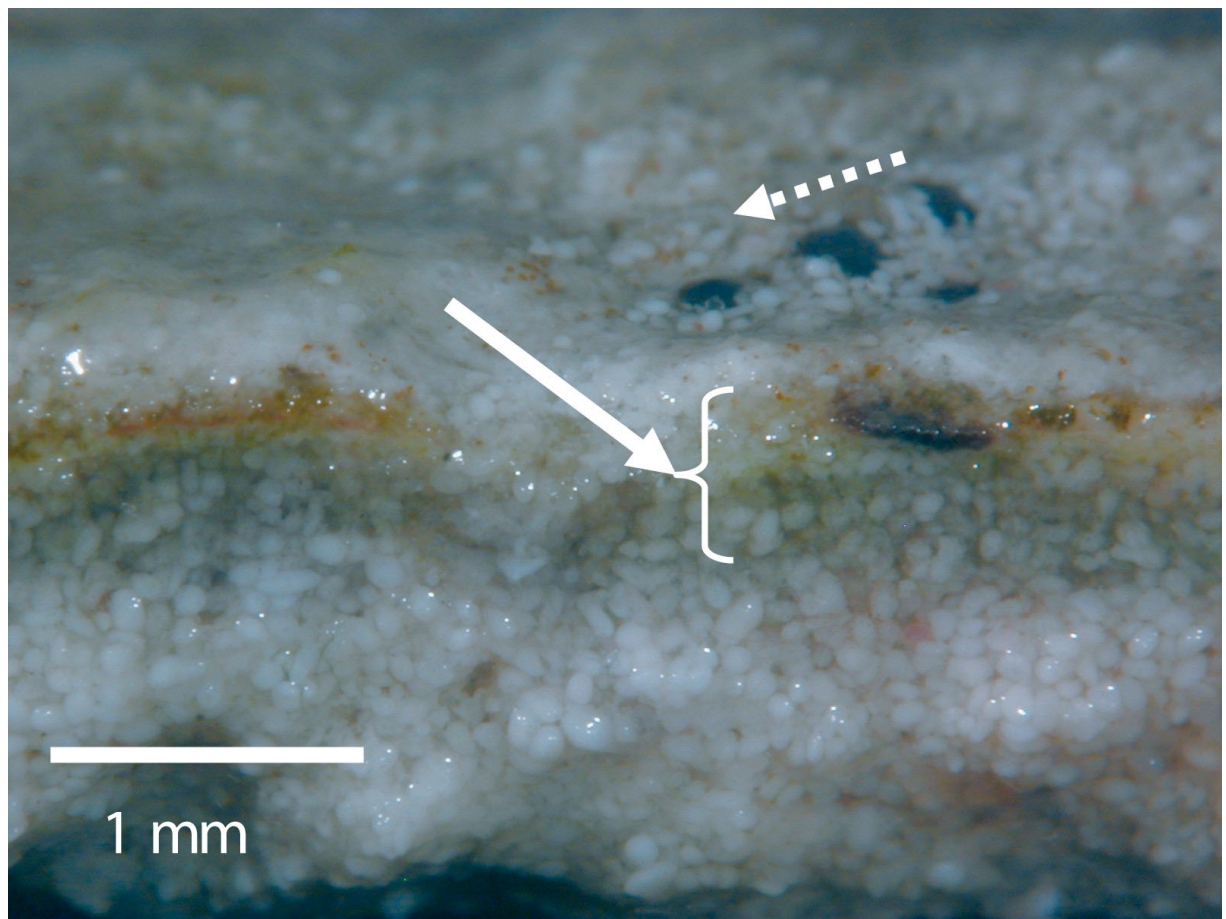

Fig. 1. Cross section of a sample of stromatolite mat collected from Highborne Cay, July 2006. The near-surface layer of cyanobacteria (identified by light microscopy) is indicated by the solid arrow. Note the lack of microalgal growth on the surface (top of image indicated by the dashed arrow) and the matrix of sand grains in the biogenic matrix

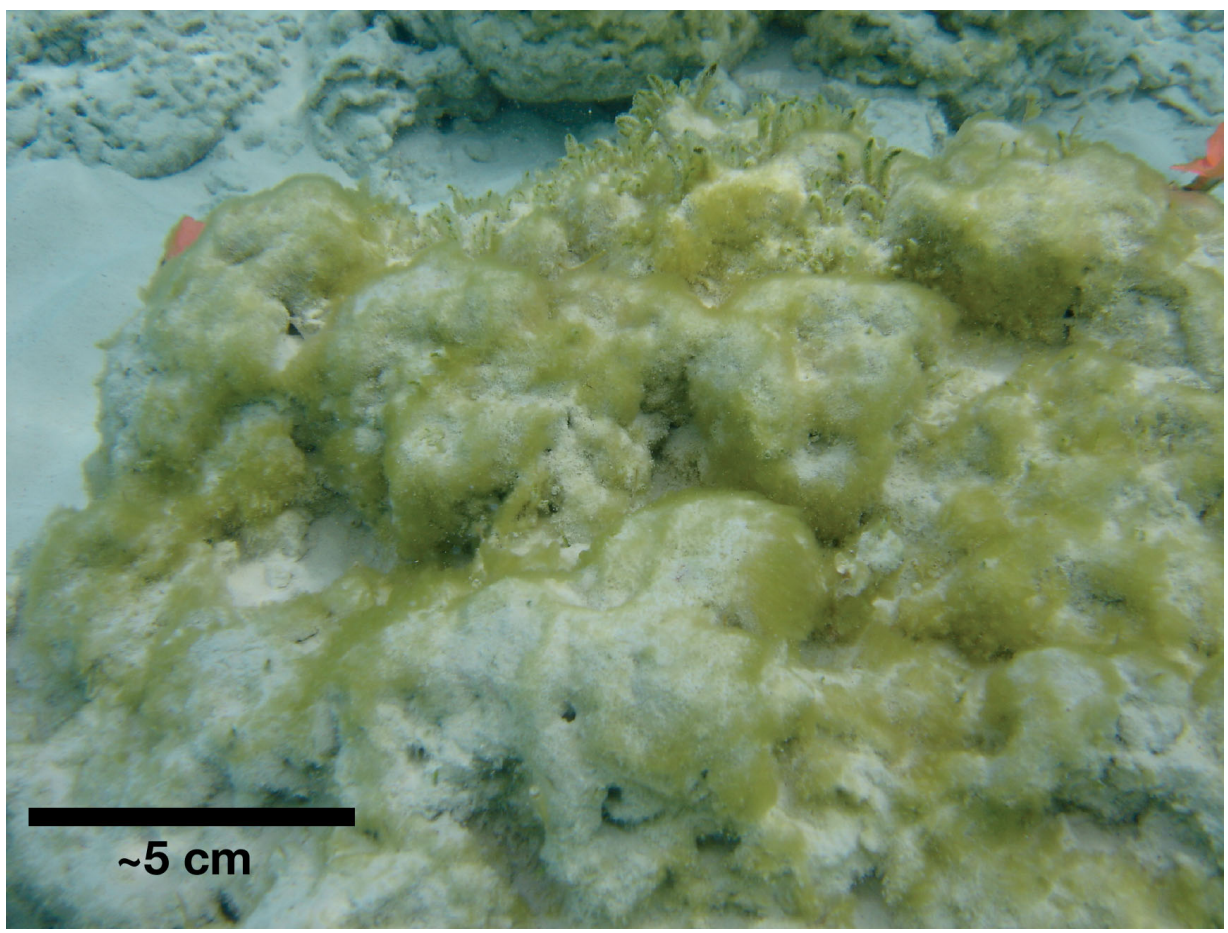

Fig. 2. Surface growth of yellow microalgae, principally the diatom Licmophora spp., on the stromatolite surface in situ at Highborne Cay, Bahamas, July 2006 
were made for samples initially kept in darkness and then exposed to low light as described above, followed by the RLC. Again, all measurements were made in triplicate, running separate samples on subsequent days. Measurements on the microalgal surface community after $\geq 7 \mathrm{~d}$ of natural in situ burial was not possible as after this duration of burial the stromatolite surface was stripped of the surface community, leaving a bare surface of sand grains and underlying cyanobacteria (R. Reid pers. comm., authors' pers. obs.).

\section{RESULTS}

\section{Initial study of artificial burial compared to dark treatment}

Photosynthetic communities of stromatolite samples buried artificially under a sand and seawater mixture showed a gradual decline in PSII quantum efficiency (Fig. 3), in sharp contrast to samples maintained ex situ in seawater and kept in darkness (with no burial). When the samples were exhumed and exposed to low light (Fig. 3, Arrow 1), PSII quantum efficiency increased, but decreased immediately when this low light was switched off temporarily (Fig. 3, Arrows 2 and 3).

\section{Naturally buried stromatolite samples}

Exposure to low light during re-burial

Photosynthetic communities of stromatolite samples that had been buried for 7 to $9 \mathrm{~d}$ in situ by natural processes were quickly sampled and returned to the laboratory for monitoring PSII reactivation. These samples had no surface microalgal growth, but had a distinct sub-surface blue-green layer of cyanobacteria. Microscopic analysis revealed a few diatom cells still present, although it was not known whether these were viable. PSII quantum efficiency (Fig. 4A) dropped rapidly once the sample had been re-buried with the fluorimeter probe in position, after returning to the laboratory. Efficiency declined to zero in $55 \mathrm{~min}$ and stayed at this level for a further $60 \mathrm{~min}$. The application of low light at 30 (Fig. 4A, Arrow 1) and $70 \mu \mathrm{mol} \mathrm{m}^{-2} \mathrm{~s}^{-1}$ PAR (Fig. 4A, Arrow 2) did not result in any recovery of quantum efficiency. However, once the sample was unburied and remained in $70 \mu \mathrm{mol} \mathrm{m} \mathrm{m}^{-2} \mathrm{~s}^{-1}$ PAR (Fig. 4A, Arrow 3), the efficiency immediately increased, showing signs of stabilising at a value greater than 0.3 after a further $120 \mathrm{~min}$.

Fluorescence kinetics (Fig. 4B) over the same experimental period showed a stable level of $F_{\mathrm{o}}$ during bur-

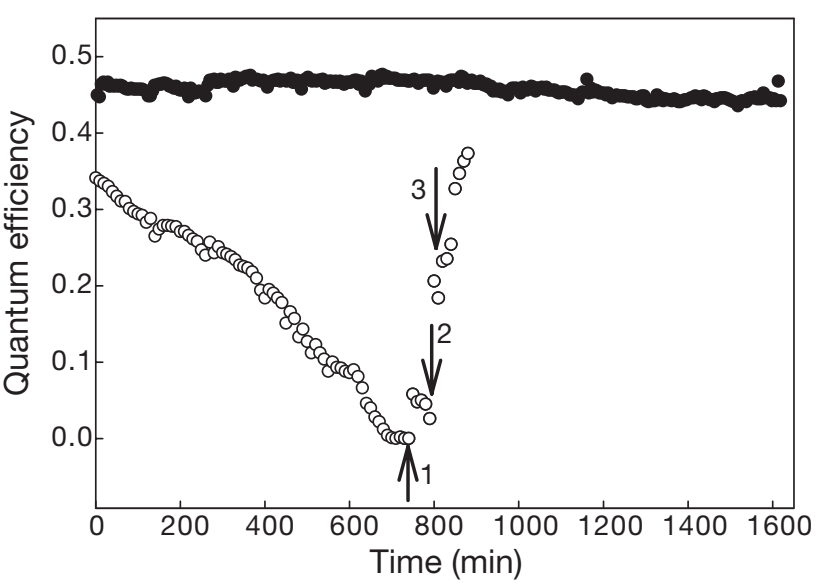

Fig. 3. Quantum efficiency (dimensionless) of the photosynthetic community of a stromatolite sample artificially buried under $3 \mathrm{~cm}$ of sand and seawater $(0)$, followed by exhumation and exposure to low light at $25 \mu \mathrm{mol}$ photons $\mathrm{m}^{-2} \mathrm{~s}^{-1}$ PAR (photosynthetically active radiation) (Arrow 1). Arrows 2 and 3 indicate periods of 40 and $10 \mathrm{~min}$, respectively, when this light was temporarily switched off. @: Control sample kept in the dark, but not buried

ial, whereas $F_{\mathrm{m}}$ decreased slightly after initial re-burial. Both fluorescence yields $\left(F\right.$ and $\left.F_{\mathrm{m}}{ }^{\prime}\right)$ then increased after application of light (Fig. 4B, Arrows 1 and 2), before declining rapidly when the sample was unburied (Fig. 4B Arrow 3). However after approximate stabilisation of $\Delta F / F_{\mathrm{m}}{ }^{\prime}, F$ then further declined, whereas $F_{\mathrm{m}}$ ' increased during the period of PSII quantum efficiency reactivation.

\section{Exposure to oxygen during re-burial}

Measurements were made similarly on samples exhumed in the field after 14 to $16 \mathrm{~d}$ of natural burial. These samples were returned to the laboratory and reburied with the fluorimeter probe and a small oxygen line in place. There was no initial PSII reactivation between sampling and re-burial (Fig 5A), with efficiency remaining at zero. The application of oxygen during burial also had no effect on PSII efficiency (Fig. 5A, Arrow 1), with an increase occurring only when the sample was exposed to low light $(70 \mu \mathrm{mol}$ $\mathrm{m}^{-2} \mathrm{~s}^{-1}$ PAR) (Fig. 5A, Arrow 2) whilst still buried. Quantum efficiency then increased, and had reached a value of only 0.1 after $60 \mathrm{~min}$. The rate of reactivation did not increase when the sample was then unburied (Fig. 5A, Arrow 3), with efficiency reaching 0.15 after a further $60 \mathrm{~min}$.

Fluorescence kinetics during the oxygen application experiments differed from those of the low light experiments in 2 distinct ways. Firstly, application of oxygen did not alter the fluorescence yields during burial 


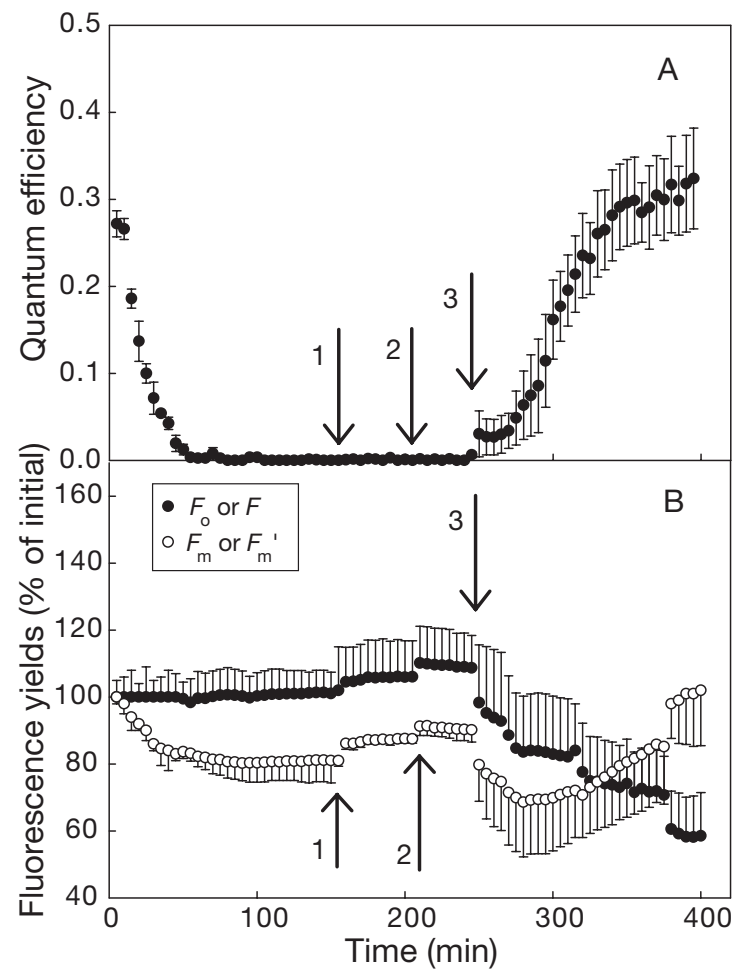

Fig. 4. (A) Quantum efficiency and (B) fluorescence yields of the photosynthetic community of stromatolite samples exhumed after 7 to $9 \mathrm{~d}$ of natural burial in situ and re-buried in the laboratory, where they were exposed to low light whilst buried, and then unburied. Means \pm SE of 3 daily replicates (one per day). Fluorescence yields were normalised as \% of initial values, and are minimum or operational yield in dark and light, respectively $(\bullet)$ and the maximum yield in dark and light (O). Arrows 1 and 2: times when low light was applied at 30 and $70 \mu \mathrm{mol}$ photons $\mathrm{m}^{-2} \mathrm{~s}^{-1}$ PAR, respectively. Arrow 3: time at which the sample was unburied, exposed to fresh seawater, and maintained in low light

(Fig. 5B, Arrow 1). Secondly, when the sample was exposed to oxygen and low light while still buried (Fig. 5B, Arrow 2), $F_{\mathrm{m}}$ ' increased rapidly and then further increased slowly; $F$ increased rapidly and then decreased slowly. Thus the order of application of light and oxygen resulted in differing fluorescence kinetic responses (cf. Figs. 4B \& 5B).

\section{Rapid light curves of unburied stromatolite samples}

After the above measurements of reactivation had been made, RLCs were obtained for each sample (Fig. 6A). Photosynthetic communities of the samples exposed to low light during burial and buried in situ for only 7 to $9 \mathrm{~d}$ had higher $\mathrm{rETR}_{\max } \alpha$ and $\mathrm{E}_{\mathrm{K}}$ than the samples exposed to oxygen during burial and buried in situ for 14 to $16 \mathrm{~d}$ (Table 2). In addition, the samples buried for 7 to $9 \mathrm{~d}$ showed no photoinhibition, whereas an obvious decrease in rETR at light levels above saturation $\left(E_{S}\right)$ indicated down regulation in samples buried for 14 to $16 \mathrm{~d}$ (Fig. 6A). Quantum efficiencies measured during both RLCs showed a steady decline as light level was increased (Fig. 6B).

\section{Reactivation of surface microalgae in artificially buried stromatolite samples}

Samples of stomatolites with extensive yellow microalgal surface growth (Fig. 2) were buried artificially under a sand and seawater mixture for $7 \mathrm{~d}$. These samples were then unburied and the fluorimeter probe was positioned selectively to detect the yields from the

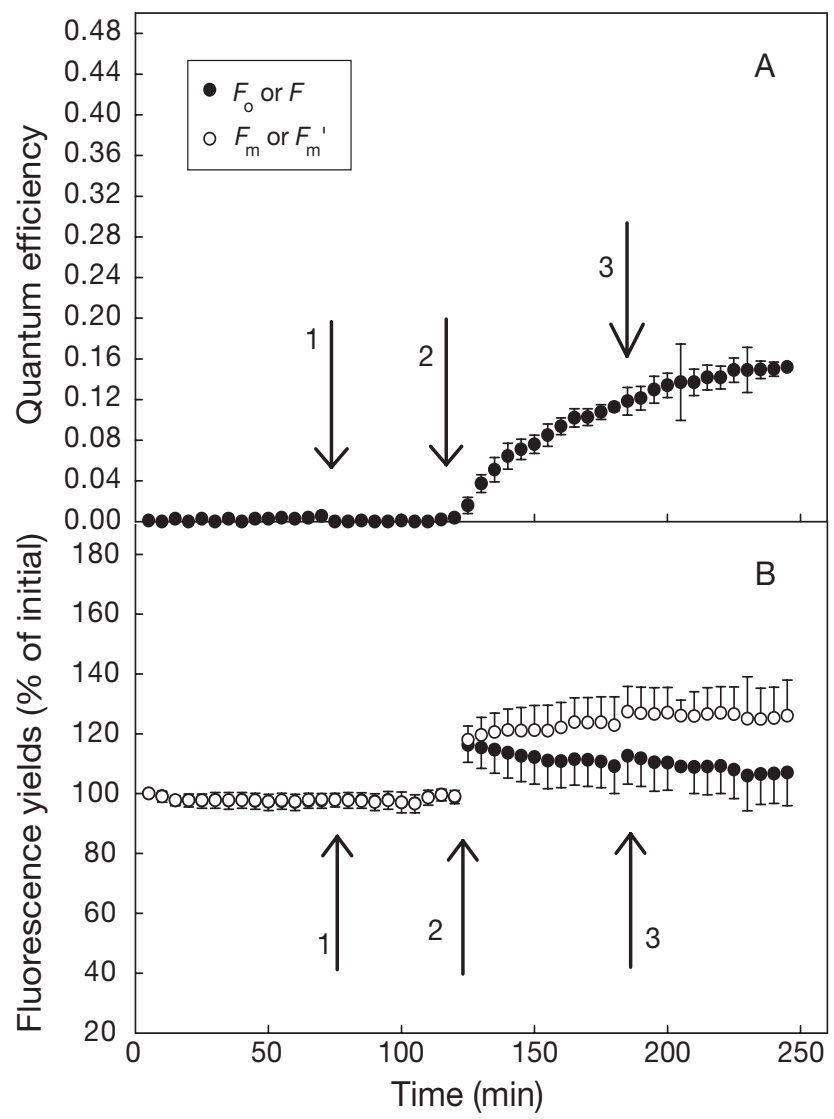

Fig. 5. (A) Quantum efficiency and (B) fluorescence yields of the photosynthetic community of stromatolite samples exhumed after 14 to $16 \mathrm{~d}$ of natural burial in situ and reburied in the laboratory, with exposure to oxygen and then low light whilst still buried. Means \pm SE of 3 daily replicates (one per day). Fluorescence yields were normalised as \% of initial values, and are minimum or operational yield in dark and light, respectively $(\bullet)$ and the maximum yield in dark and light $(0)$. Arrow 1: time at which oxygen was applied, Arrows 2 and 3: times at which low light was applied at 30 and $70 \mu \mathrm{mol}$ photons $\mathrm{m}^{-2} \mathrm{~s}^{-1} \mathrm{PAR}$, respectively 


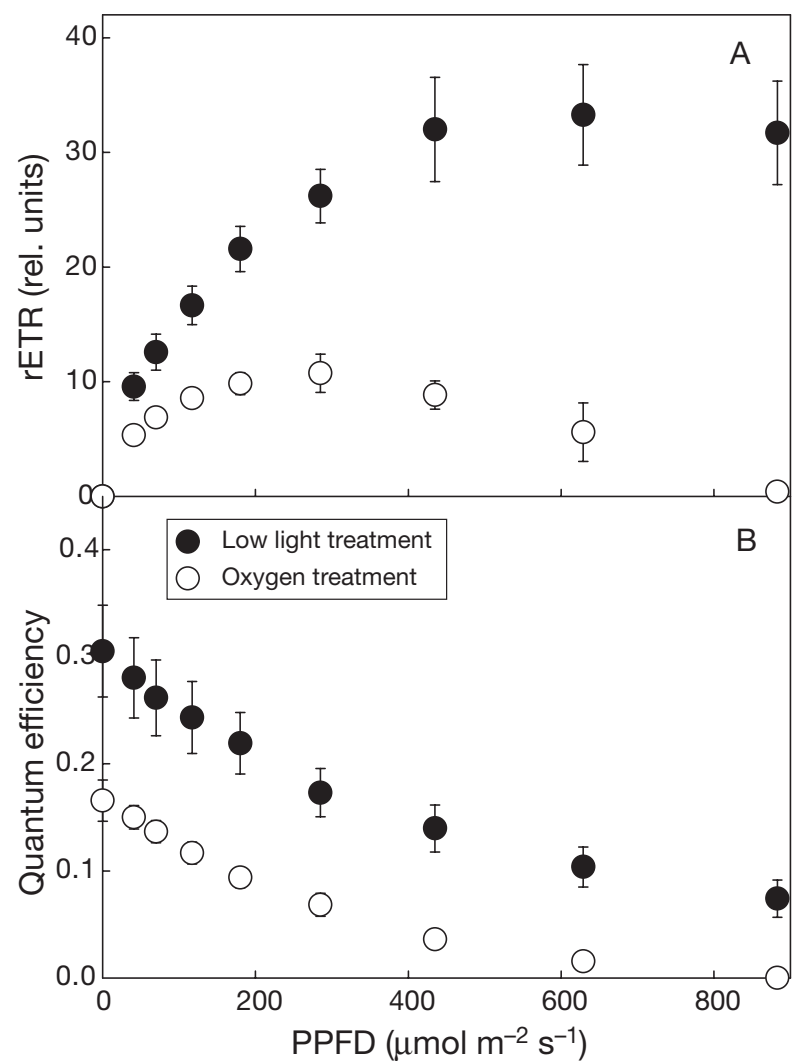

Fig. 6. Rapid light curves (RLC) of (A) relative electron transport rate and (B) quantum efficiency, for the photosynthetic community of stromatolite samples measured following exposure to low light (low light treatment as per Fig. $4 ; \bullet$ ) and oxygen (oxygen treatment as per Fig, $5 ;$ O). Means \pm SE of 3 daily replicates (one per day). rel. = relative

surface microalgae without interference from underlying cyanobacteria. The density of microalgal growth, assessed visually, had decreased. Two of 3 replicates showed no recovery of PSII efficiency when unburied, with the quantum efficiency remaining at zero, despite exposure to darkness, low light and enhanced oxygen potential achieved by bubbling the overlying water with oxygen. Fluorescence yields for these 2 samples declined slowly over the measurement period (Fig. 7), with $F_{\mathrm{o}}$ and $F_{\mathrm{m}}$ of the same magnitude. When RLCs were obtained for these samples, quantum efficiency, and hence rETR, remained at zero. The third sample showed some reactivation, similar to the cyanobacteria described above. When unburied, PSII efficiency increased steadily when low light was applied at 30 and $70 \mu \mathrm{mol} \mathrm{m} \mathrm{m}^{-2} \mathrm{~s}^{-1}$ (Fig. 8, Arrows 1 and 2, respectively). After low light for $180 \mathrm{~min}$, the quantum efficiency had increased to 0.08 , demonstrating a very small recovery compared to the value of $0.53 \pm 0.12$ (mean $\pm \mathrm{SE}$ ) for the 3 samples prior to burial. Analysis of the fluorescence kinetics for this reactivation period
Table 2. Rapid light curve (RLC) parameters obtained for samples after low light ( 7 to $9 \mathrm{~d}$ burial) and after oxygen and low light (14 to $16 \mathrm{~d}$ burial) treatments. $\mathrm{rETR}_{\max }=$ maximum relative electron transport rate; $\alpha=$ initial slope of the RLC; $\mathrm{E}_{\mathrm{K}}=$ light use coefficient. Means $\pm \mathrm{SE}, \mathrm{n}=3$. PAR $=$ photosynthetically active radiation; rel. $=$ relative

\begin{tabular}{|lcc|}
\hline Parameter & $\begin{array}{c}\text { Low light/unburial } \\
\text { treatment }\end{array}$ & $\begin{array}{c}\text { Oxygen/low } \\
\text { light treatment }\end{array}$ \\
\hline rETR $_{\max }$ (rel. units) & $34 \pm 4$ & $10 \pm 2$ \\
$\alpha$ (rel. units) & $0.25 \pm 0.016$ & $0.125 \pm 0.007$ \\
$\mathrm{E}_{\mathrm{K}}\left(\mu \mathrm{mol} \mathrm{m}{ }^{-2} \mathrm{~s}^{-1} \mathrm{PAR}\right)$ & $130 \pm 20$ & $80 \pm 9$ \\
\hline
\end{tabular}

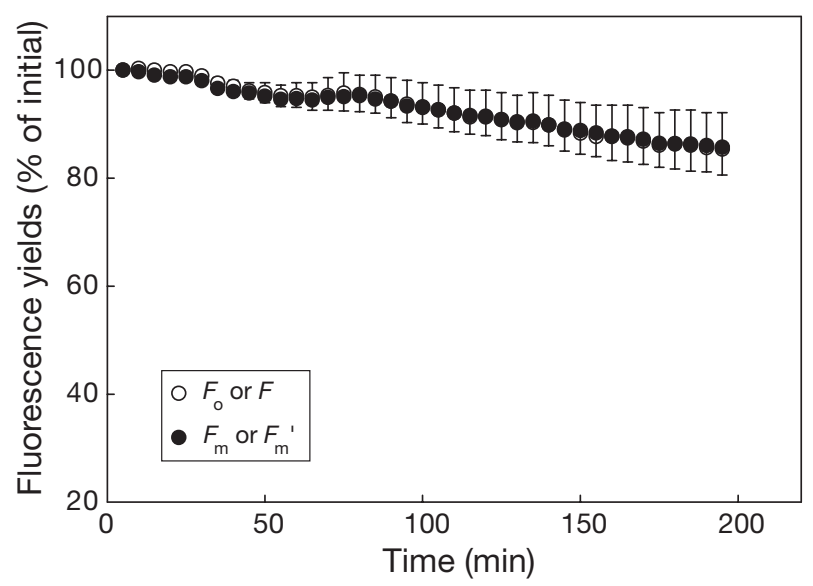

Fig. 7. Fluorescence yields of minimum or operational yield in dark and light, respectively $(\bullet)$ and the maximum yield in dark and light $(\mathrm{O})$ for the photosynthetic stromatolite surface diatom community exhumed after $7 \mathrm{~d}$ artificial burial in sand and seawater. Samples were exposed to light $(70 \mu \mathrm{mol}$ photons $\mathrm{m}^{-2} \mathrm{~s}^{-1} \mathrm{PAR}$ ). Yields were normalised as \% of initial values. Means \pm SE of 2 samples measured on successive days

showed a steady decline in both $F$ and $F_{\mathrm{m}}{ }^{\prime}$ (Fig. 8), once the sample had been exposed to low light. At the end of this period, a RLC indicated clear down regulation at light levels above $\mathrm{E}_{\mathrm{S}}$ (about $400 \mu \mathrm{mol} \mathrm{m} \mathrm{m}^{-2} \mathrm{~s}^{-1}$ PAR), an $\mathrm{rETR}_{\max }$ of 7 relative units, $\alpha$ of 0.12 relative units and $E_{K}$ of $150 \mu \mathrm{mol} \mathrm{m}{ }^{-2} \mathrm{~s}^{-1}$ PAR.

\section{DISCUSSION}

We demonstrated a potential ability of the cyanobacteria found in modern stromatolites at Highborne Cay, Bahamas to tolerate at least medium duration (up to $2 \mathrm{wk}$ ) burial by sand in situ. The ability of these taxa to withstand the associated stresses of anoxia and darkness for this length of time may, in part, account for the predominance of cyanobacteria in stromatolite formations over geological time scales. In comparison, the 


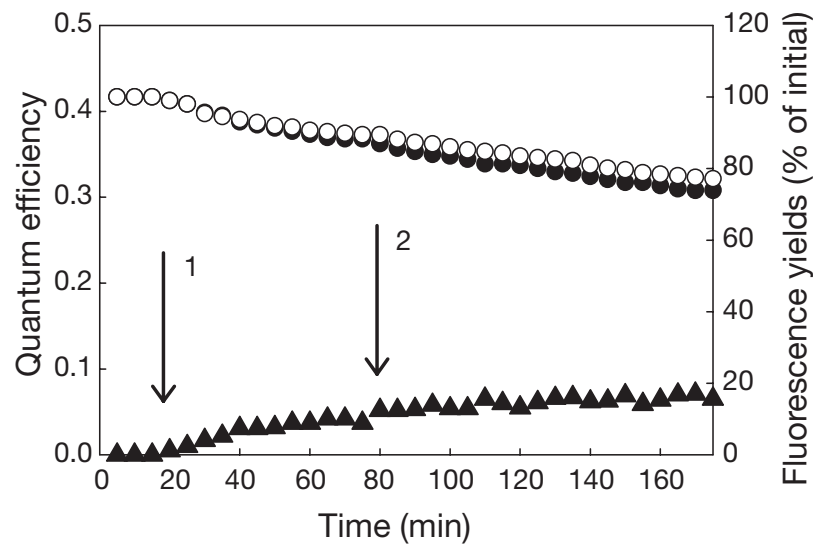

Fig. 8. Quantum efficiency ( $\mathbf{\Lambda}$ ) and fluorescence yield of minimum or operational yield in the dark and light, respectively $\left(F_{\mathrm{o}}, F_{;} \bullet\right)$, and the maximum yield in the dark and light $\left(F_{\mathrm{m}}\right.$ $F_{\mathrm{m}}{ }^{\prime} ;$ O) for the photosynthetic diatom community of a stromatolite sample exhumed after $7 \mathrm{~d}$ artificial burial in sand and seawater. Arrows 1 and 2 indicate the times when exposed to low light at 30 and $70 \mu \mathrm{mol} \mathrm{m}{ }^{-2} \mathrm{~s}^{-1}$ PAR (photosynthetically active radiation), respectively. Fluorescence yields were normalised as \% of initial values. Data from a single sample measured as the third replicate of the data presented in Fig. 7, with one replicate measured on each of 3 successive days

ability of the diatoms colonising the surface of the stromatolite to tolerate burial conditions appeared to be far lower, with only 1 of 3 samples surviving after just a single week's burial. Modern stromatolites form in dynamic systems, where turbulence provides the sediment for 'growth'. It has been hypothesised that both microalgae and cyanobacteria play important roles in trapping and binding these particles (Riding et al. 1991, MacIntyre et al. 2000, Reid et al. 2000). Whilst the data presented here do not resolve the debate on the relative importance of prokaryotes and eukaryotes in these processes, they do suggest a persistence of cyanobacteria, due to the ability of the cyanobacterial community to survive burial by sand in situ, a process occurring frequently in these dynamic systems.

Cyanobacteria inactivated their photosynthetic processes, or at least those associated with PSII activity, during burial when deprived of both light (Fig. 3) and oxygen (Kromkamp et al. 2007). In contrast, darkness alone resulted in a stable quantum efficiency typical of most photosynthetic taxa, e.g. diatoms and green microalgae (e.g. Ting \& Owens 1993). These data (Figs. 4 \& 5) demonstrate that during and after burial, PSII activity will recover only when both oxygen and low light are applied, or become naturally available. These are likely stimuli in the natural environment when the stromatolites become unburied following periods of sand burial. Thus adaptation to enable inactivation and reactivation of PSII activity may be an advantage to frequently buried cyanobacteria in stro- matolite systems. In comparison, surface microalgae are very likely scoured off the stromatolite surface, due to their exposure to greater hydrodynamic stresses and sand grain scour (R. Reid pers. comm., authors' pers. obs.). As a result, these taxa may not persist on the stromatolite surface after burial periods of weeks or longer, suggesting that development of this ability to inactivate and restore PSII function, or similar adaptations would not be as beneficial. Such an hypothesis is supported by the data for the 3 diatom samples buried artificially, 2 of which showed no PSII recovery and one sample which showed a low level of recovery (Figs. $7 \&$ 8).

Analysis of the fluorescence kinetics demonstrated a varying response of the cyanobacteria depending upon the order of exposure to oxygen and low light (it is possible, although unlikely, that the duration of burial may have caused this variation in response). When light was applied during burial, both $F$ and $F_{\mathrm{m}}$ ' increased, suggesting a state transition from State 2 to State 1 (Schreiber et al. 1995, Campbell et al. 1998, Schreiber et al. 2002). Once unburied, both fluorescence yields ( $F$ and $F_{\mathrm{m}}{ }^{\prime}$ ) of cyanobacteria decreased prior to a continued decrease in $F^{\prime}$ and an increase in $F_{\mathrm{m}}{ }^{\prime}$. This suggests that the exposure to oxygen has then induced some form of oxygen-dependent electron transport, possibly through Mehler type reactions and/or respiration (Asada 2000), which has 'kickstarted' electron transport prior to induction of photosynthetic electron transport, hence restoring variable fluorescence (an increase in $F_{\mathrm{m}}{ }^{\prime}$ and a decrease in $F^{\prime}$ ). In turn, light may activate enzymes associated with Rubisco activity (e.g. Rubisco activase; Salvucci et al. 1985, Salvucci \& Ogren 1996, Jensen 2000), also contributing to induction of photochemistry. These above processes have been used to explain the reactivation of desiccated beach-rock microbial mats after rehydration (Schreiber et al. 2002).

In contrast to the exposure to light prior to oxygen, when oxygen was bubbled to buried samples, there was no change in fluorescence yields when light was later applied, other than a rapid increase in yields (Fig. 5, Arrow 2) and then a decrease in $F^{\prime}$ and an increase in $F_{\mathrm{m}}{ }^{\prime}$. There was therefore no evidence of a State 2 to State 1 transition during burial, and hence no opposing transition when light was applied. The rapid increase in yields ( $<5 \mathrm{~min}$ ) may have been rapid state transition, or possibly increased detection of fluorescence yields during unburial of the sample. El Bissati et al. (2000) note that state transitions may be as rapid as $150 \mathrm{~s}$ at $30^{\circ} \mathrm{C}$, and only $700 \mathrm{~s}$ at $10^{\circ} \mathrm{C}$. However, after this point, the decline in $F^{\prime}$ and the increase in $F_{\mathrm{m}}$ ' indicated restoration of variable fluorescence and hence photochemical activity. The data from both treatments (low light/unburial and oxygen/low light) suggest a 
probable photoprotective role of oxygen dependent electron transport in stromatolite cyanobacteria, hence preventing or minimising photoinhibition upon exposure to light. This reinforces the role of oxygen in inactivation and reactivation of photochemistry as a result of burial and unburial, respectively. The RLC parameters $\left(\mathrm{rETR}_{\max }, \alpha, \mathrm{E}_{\mathrm{K}}\right.$ i Table 2) obtained for samples reactivated after 14 to $16 \mathrm{~d}$ burial were lower than those for samples buried for only 7 to $9 \mathrm{~d}$. This suggests that the reactivation processes suggested above were induced more slowly as a result of the longer burial period. Further work is needed to investigate the duration of burial that can be tolerated by the cyanobacterial community.

The diatoms at the surface of the stromatolites fared less well when artificially buried for $7 \mathrm{~d}$. Artificial burial may be more severe than natural burial in situ however, with more rapid induction of anoxia due to reduced percolation of seawater in the overlying sand because of a lack of turbulence-induced mixing of the overlying layers. However, natural burial is likely to induce higher physical scouring. Nevertheless, the reactivation of the diatoms after natural burial is not possible as they are removed by the in situ burial process (R. Reid pers. comm., authors' pers. obs.) (Fig. 1). This in itself demonstrates a lack of ability to tolerate burial, possibly as a result of the growth form of this periphyton. However, the reduced ability of the diatoms to reactivate PSII activity after burial (compared to the cyanobacteria) reinforces acceptance of the notion that cyanobacteria survive natural burial events, whereas diatoms (and probably other microbial photosynthetic eukaryotes in stromatolite photosynthetic communities) do not. Analysis of the fluorescence kinetics for the diatoms after burial, indicated a general decline in fluorescence yields, with a decline in $F_{\mathrm{m}}$ ' less than that of $F^{\prime}$, indicating a partial restoration of photochemistry through reoxidation of the PQ (plastoquinone) pool. The decline in yields may have been due to non-photochemical quenching (Ting \& Owens 1993), although as the decline occurred in samples which showed no restoration of PSII activity, this seems unlikely. Finally, the $\mathrm{rETR}_{\max } \alpha$ and $\mathrm{E}_{\mathrm{K}}$ values obtained from the light curve for the diatom sample that did reactivate after burial were very low, suggesting the cells were in poor condition.

To summarise, in contrast to surface photosynthetic microbial eukaryotes, principally diatoms, cyanobacteria within the surface fabric of the stromatolite were able to use oxygen and light as stimuli to inactivate and reactivate their PSII photochemistry. Reactivation is possible after at least 2 wk of natural in situ burial. The suggested processes for reactivation include oxygen-dependent and light-activated restoration of photochemistry through oxidation of the plasto- quinone pool. This is most likely a combination of Mehler reactions and respiration and light-induced activation of Calvin cycle enzymes. Such an ability to tolerate medium (1 mo) to potentially long term burial (several months to $>1$ yr) may be a distinct advantage to stromatolite cyanobacteria, explaining their importance in the ecosystem function of stromatolite construction over historical time scales.

Acknowledgements. Many thanks to the ship's crew and fellow science crew on board the RV 'F.G. Walton Smith' for their support during this work. This study was funded by the National Science Foundation. R.G.P. was in part supported by a Cardiff University research travel grant. This is RIBS publication No. 38 and NIOO-KNAW publication No. 4070.

\section{LITERATURE CITED}

Andres MS, Sumner DY, Reid RP, Swart PK (2006) Isotopic fingerprints of microbial respiration in aragonite from Bahamian stromatolites. Geology 34:973-976

Asada A (2000) The water-water cycle as alternative photon and electron sinks. Philos Trans R Soc Lond B 355: 1419-1431

Browne KM, Golubic S, Lee SJ (2000) Shallow marine microbial carbonate deposits. In: Riding R, Awramik SM (eds) Microbial sediments. Springer-Verlag, Berlin, p 233-249

Campbell D, Hurry V, Clarke AD, Gustafsson P, Öquist G (1998) Chlorophyll fluorescence analysis of cyanobacterial photosynthesis and acclimation. Microbiol Mol Biol Rev 62:667-683

Dill RF, Shinn EA, Jones AT, Kelly K, Steinen RP (1986) Giant subtidal stromatolites forming in normal salinity waters. Nature 324:55-58

Eilers PCH, Peeters JCH (1988) A model for the relationship between light intensity and the rate of photosynthesis in phytoplankton. Ecol Model 42:199-215

El Bissati K, Delphin E, Murata N, Etienne AL, Kirilovsky D (2000) Photosystem II fluorescence quenching in the cyanobacterium Synechocystis PCC 6803: involvement of two different mechanisms. Biochim Biophys Acta 1457: 229-242

Genty B, Briantais JM, Baker NR (1989) The relationship between quantum yield of photosynthetic electron transport and quenching of chlorophyll fluorescence. Biochim Biophys Acta 990:87-92

Jensen RG (2000) Activation of Rubisco regulates photosynthesis at high temperature and $\mathrm{CO}_{2}$. Proc Nat Acad Sci USA 97:12937-12938

Kromkamp JC, Perkins RG, Dijkman N, Consalvey M, Andres M, Reid RP (2007). Resistance to burial of cyanobacteria in stromatolites. Aquat Microb Ecol 48:123-130

Macintyre IG, Prufert-Bebout L, Reid RP (2000) The role of endolithic cyanobacteria in the formation of lithified laminae in Bahamian stromatolites. Sedimentology 47: 915-921

Perkins RG, Mouget JL, Lefebvre S, Lavaud J (2006) Light response curve methodology and possible implications in the application of chlorophyll fluorescence to benthic diatoms. Mar Biol 149:703-712

Reid P, Visscher PT, Decho AW, Stolz JF and 8 others (2000) The role of microbes in accretion, lamination and early lithification of modern marine stromatolites. Nature 406: 989-992 
Riding R (2000) Microbial carbonates: the geological record of calcified bacterial-algal mats and biofilms. Sedimentology 47:179-214

Riding R, Awramik SM, Winsborough BM, Griffin KM, Dill RF (1991) Bahamian giant stromatolites: microbial composition of surface mats. Geol Mag 128:227-234

Sakshaug E, Bricaud A, Dandonneau Y, Falkowski P and 5 others (1997) Parameters of photosynthesis: definitions, theory and interpretation of results. J Plankton Res 19: 1637-1670

Salvucci M, Ogren W (1996) The mechanism of Rubisco activase: insights from studies of the properties and structure of the enzyme. Photosynth Res 47:1-11

Salvucci M, Portis A, Ogren W (1985) A soluble chloroplast protein catalyzes ribulosebisphosphate carboxylase/ oxygenase activation in vivo. Photosynth Res 7:193-201

Editorial responsibility: Otto Kinne (Editor-in-Chief), Oldendorf/Luhe, Germany
Schreiber U, Endo T, Mi H, Asada A (1995) Quenching analysis of chlorophyll fluorescence by the saturation pulse method: particular aspects relating to the study of eukaryotic algae and cyanobacteria. Plant Cell Physiol 36:873-882

Schreiber U, Gademann R, Bird P, Ralph PJ, Larkum AWD, Kuhl M (2002) Apparent light requirement for activation of photosynthesis upon rehydration of desiccated beachrock microbial mats. J Phycol 38:125-134

Ting CS, Owens TG (1993) Photochemical and nonphotochemical fluorescence quenching processes in the diatom Phaeodactylaum tricornutum. Plant Physiol 101: 1323-1330

Visscher PT, Reid RP, Bebout BM (2000) Microscale observations of sulfate reduction: correlation of microbial activity with lithified micritic laminae in modern marine stromatolites. Geology 28:919-922

Submitted: February 27, 2007; Accepted: May 25, 2007 Proofs received from author(s): October 16, 2007 